\title{
Ti år med Kofi Annan
}

\section{Kirsten Larsen}

Han blev klappet ind i FN-bygningen af medarbejderne, da han den 2. januar 1997 for første gang gik på arbejde som FN's generalsekretær. Som altid elegant klædt, rank og roligt smilende. Men ikke uplettet af fortiden. Uhyrlighederne fra især Rwanda skæmmer billedet af en af FN's formentlig allerdygtigste generalsekretærer

Fra nu af er det tilladt at tale med hinanden, og hvis I har noget på sinde er I velkomne til at komme til mig. Det var hovedindholdet i et par breve Kofi Annan sendte til sine nærmeste underordnede, altså FN's øvrige topchefer, kort tid efter at han var tiltrådt. For sådan var det system, han arvede efter Boutros Ghali. Undergeneralsekretærerne, altså et diplomatisk niveau som regeringer slås om at besætte med topfolk, måtte ikke holde møder uden generalsekretærens billigelse. $\mathrm{Og}$ da slet ikke træffe beslutninger på det politiske niveau.

FN's administrative chef, den daværende amerikanske undergeneralsekretær Joseph Connor, skulle personligt godkende hver eneste flybillet og særtilladelse til at flyve på Bu- siness Class - noget almindelige FNdiplomater kun må, når flyvetiden overstiger en 8-9 timer.

Computere, det var noget man skrev på. Et sammenhængende system fandtes ikke. Når der opstod en nødsituation eller konflikt et sted i verden, og det gjorde der ofte i de år, ja så havde FN ingen database over egne medarbejdere og deres kvalifikationer. Når der blev iværksat en aktion, ja så måtte man ringe rundt til afdelinger, organisationer og enheder i og uden for $\mathrm{FN}$ for at høre, om de havde medarbejdere, der havde forstand på dette eller hint.

Ville man som journalist tale om en eller anden problemstilling, ja så var det som oftest uden for citat. Det skulle godkendes centralt og arran- 
geres gennem talsmandens kontor, hvis der skulle navn eller måske stemme eller ansigt på en udtalelse.

Systemet var gammeldags, topstyret og stift. Moralen var lav, kassen tom og hele $\mathrm{FN}$ var under heftigt angreb fra den amerikanske kongres.

USA skyldte 1,3 milliarder dollar, da den dengang 58 år gamle Kofi Annan blev valgt med Washingtons ihærdige opbakning. Han blev, lige som efterfølgeren Ban Ki-Moon netop er blevet det, udpeget, fordi han var mere sekretær end general, fordi han ikke generede nogen, hvis han kunne undgå det, fordi han kendte sin plads. Men fra dem, der kendte Kofi Annan, lød det nærmest samstemmende - det her er for godt til at være sandt.

\section{Diplomatiets superstar}

Han blev internationalt diplomatis rockstjerne i løbet af de første fem år. Generalsekretæren trak fulde huse over alt i verden. Et moralsk fyrtårn, en ledestjerne, en verdslig pave er nogle af de udtryk, som ofte er blevet brugt i de tusinder af artikler, der er blevet skrevet om Kofi Annan. Men ud over alle de store ord, så er der et enkelt, der går igennem i næsten hver eneste tekst, der har skullet beskrive ham. Soft-spoken hedder det om generalsekretæren i de fleste engelske tekster. Og soft-spoken er han, manden der stort set aldrig hæver stemmen, men til gen- gæld mestrer evnen til at tale lavere, når der er uro omkring ham, med det resultat at alle tier og lytter.

Høvdingesønnen fra Ghana, uddannet på kristen skole i sit hjemland, i USA's midtvesten, i Schweiz og på USA's østkyst, har udviklet en stærk forståelse for, hvad der betyder noget, for de mennesker han taler med. Ifølge hans nærmeste medarbejdere, så husker han altid at spørge til familien, til børnene eller den syge mor - uanset om det er en dørmand i FN eller en regeringschef, han møder. Efter sigende roder han aldrig rundt i hvem, der er hvem, når han til generalforsamlingens åbning hvert år i september trykker hænder og holder møder på samlebånd.

Generalsekretæren og hans svenske kone Nane Annan er et efterspurgt par i New Yorks sociale liv, og de deltager gerne i det. Hun er Raoul Wallenbergs niece - diplomaten der reddede mange jøder ud af Tyskland under Anden Verdenskrig, før han forsvandt i Sovjetunionen i 1945. En familie, der bestemt ikke har været til ugunst for generalsekretæren i USA.

Længe gik det godt. Kofi Annan lagde meget hurtigt sin første reformplan på bordet. En plan for hvordan FN-systemet skulle fungere bedre og mere effektivt. Skuffende for dem, der ville have en anden verdensorden, men aldeles afgørende for systemet, både som arbejdsplads og som internationalt værktøj. Han fik 
det ikke, som han ville have det på alle punkter. Generalsekretærens ret til selv at flytte rundt på både medarbejdere og penge er stadig meget begrænset - næsten ikke eksisterende. Et forsøg på at samle de selvstyrende særorganisationer i FN under en hat blev også forpurret - af den amerikansk ledede børneorganisation UNICEF der fik mobiliseret kongressen imod det projekt. Men FN kom ud af hele processen som en slankere og mere nutidig organisation. Og det lykkedes både at få USA til at betale det meste af gælden og at trække Washington længere ind i det internationale samarbejde.

USA's FN-ambassadør og derefter udenrigsminister Madeleine Allbright har altid nægtet, at hun råbte ad Kofi Annan, da han i 1998 fortalte at han ville tage til Irak for at forhandle med Saddam Hussein for at undgå en krig. Men medarbejdere fastholder, at hun kunne høres hele vejen ned ad gangen og i øvrigt også skingrede ud gennem generalsekretærens telefon. Han drog af sted alligevel og kom også tilbage med en aftale med Iraks diktator. Aftalen holdt ikke længe, men det var ifølge generalsekretæren ikke grund til at lade være med at prøve.

Turen til Irak var et af de forholdsvis tidlige tegn på, at Kofi Annan havde i sinde at være andet og mere end sekretær. For hans følgesvende var den også et bevis på den ro, han besidder. Generalsekretæren satte sig til at sove i flyet til Bagdad, på vej til sin på det tidspunkt største diplomatiske satsning.

\section{Rædslerne i Rwanda}

Ro, værdighed og moral synes i det hele taget at kendetegne generalsekretærens virke, med især en skræmmende og skæmmende undtagelse - folkedrabet i Rwanda. Efter alt at dømme undlod Kofi Annan som chef for den fredsbevarende afdeling at sende en advarsel om det forestående folkedrab videre op i systemet. At FN ikke reagerede på advarslen, det kan der være gode grunde til. På det tidspunkt druknede FN-diplomaterne i kriser og katastrofer. Annan havde netop fået til opgave at få styr på den kaotiske situation i den fredsbevarende afdeling. Efter årtiers nærmest stilstand under den Kolde Krig havde FN gang i 16 fredsbevarende operationer uden på nogen måde at være gearet til det. Det fredsbevarende arbejde var netop blevet trukket ud af den politiske afdeling. Men det var først og fremmest den politiske afdeling og generalsekretær Boutros Ghalis kontor, der stod for Rwanda. Og fra generalsekretærens særlige udsending i Rwanda lød der helt andre toner end fra den canadiske general, som sendte advarslen om det kommende folkedrab.

Da først folkedrabet blev indledt den 6. april 1994, blev der heller ikke råbt højt fra Kofi Annan. FN's top tegnede et billede af et lille 
land, hvor indbyggerne var gået amok i blodrus. Langt senere fik offentligheden kendskab til, at landets mindretal var søgt systematisk udryddet.

\section{Det må ikke ske igen}

Uanset hvad den daværende undergeneralsekretær havde sagt, ville det formentlig ikke have gjort en forskel. FN's store medlemslande vidste, hvad der foregik, og ville ikke sende soldater til det lille, fattige centralafrikanske land, og det ville de fleste mindre lande heller ikke. Medierne var ligeglade. Men måske havde der været en chance for at få iværksat et kraftigere forsøg på at stoppe myrderierne, hvis der havde været større offentlighed om, hvad der skete. Og det kunne Kofi Annan - måske - have sørget for. Han skulle have råbt $\mathrm{op}$, men han tav.

Annan kom til at tage hele balladen. Al kritik af generalsekretær Boutros Ghali for hans rolle i forhold til Rwanda blev rettet mod Annan, da han overtog topposten. Egyptiske Boutros Ghali blev belønnet for sit gode forhold til Frankrig med topposten for sammenslutningen af de frankofone lande. I øvrigt er Frankrig stadig under anklage for sin støtte til det daværende regime i Rwanda. I begyndelsen af november $i$ år frigav det franske forsvarsministerium over 100 fortrolige dokumenter til brug i en retssag som seks overlevende rwandere har rejst mod
Frankrig for meddelagtighed i folkedrab.

Kritikken blev som sagt næsten udelukkende rettet mod Annan fra det øjeblik han overtog tøjlerne i FN. Han har taget imod. Uden at prøve at skubbe skylden over på andre, det kunne formentlig heller ikke have ladet sig gøre. Mere bemærkelsesværdigt er det, at han iværksatte undersøgelser - ikke bare af FN's rolle i Rwanda, men også af massakren i Srebrenica i Bosnien, som også fandt sted på hans vagt som undergeneralsekretær for den fredsbevarende afdeling. Den massakre er han aldrig blevet klandret for i synderlig grad. Det er alment kendt, at FN's sekretariat forgæves prøvede at tale Sikkerhedsrådet fra at oprette de såkaldt sikre områder i Bosnien uden at bevilge de nødvendige soldater til også at sikre dem

Rapporterne var gyselige. Sørgelige. De beskrev nøgternt et system, der var svagt, fejt, inkompetent og overdrevent bureaukratisk. Men ifølge The International Peace Academy $\mathrm{i}$ New York, var modtagelsen af rapporterne i FN nærmest revolutionerende. Der blev ikke gjort forsøg på at bortforklare eller nedtone konklusionerne. Tværtimod. Undersøgelserne trak endnu en med sig Brahimi-rapporten, som skulle se på hele FN's fredsbevarende arbejde og prøve at sikre at historien ikke gentager sig. Og det var også det, der lå bag Kofi Annans efterhånden berømte tale til generalforsamlingen i 
1999, da han til mange regeringers fortrydelse gjorde op med princippet om ikke at blande sig i staters indre forhold, hvis de samme stater begik grove overgreb mod egne indbyggere. Siden har alverdens lande skrevet under på forpligtelsen til at gribe ind i sådanne tilfælde. Men som situationen i Darfur vidner om, så er Sikkerhedsrådets medlemmer ikke rede til at følge de retningslinjer. Og som generalsekretæren siden har udtalt - hvis situationen i Rwanda skulle gentage sig, så ville han formentlig heller ikke være i stand til at stoppe det i dag

Sikkerhedsrådets medlemmer tog imod Rwanda og Srebrenica-rapporterne i næsten rungende tavshed, selv om de bestemt ikke gik ram forbi - især ikke de fem faste medlemmer. Men den nuværende amerikanske FN-ambassadør John Bolton, der under Clinton-administrationen var vicedirektør i the American Enterprise Institute gav allerede dengang generalsekretæren tørt på for at have overskredet sine beføjelser ved at have iværksat en undersøgelse, som endte med at kritisere nogle af FN's medlemslande. Han sagde, at FN's generalsekretær var ved at udvikle en bekymrende opførsel. Som international embedsmand havde Annan ingen ret til at kritisere medlemmers handlinger.

Kofi Annan viste sig mere og mere selvstændig. Og steg i verdens agtelse. Kulminationen kom i år $2000 \mathrm{og}$ 2001 ved Årtusindtopmødet, da stats- og regeringschefer skrev under på visioner for en bedre verden, $o g$ da han på sine og FN's vegne modtog Nobels Fredspris. Kofi Annan blev måneder før hans embedsperiode udløb genudnævnt til yderligere fem år på posten. Fem år op ad bakke skulle det vise sig.

\section{Under angreb}

Terrorangrebene på World Trade Center og Pentagon 11. September 2001. Krig i Afghanistan. Krigen mod Irak, som han selv siger er hans allerstørste nederlag, at han ikke kunne forhindre. Bombesprængningen af FN's hovedkvarter i Bagdad, hvor 22 kollegaer deriblandt generalsekretærens nære ven Sergio de Mello blev dræbt. En begivenhed, der fik generalsekretæren til offentligt at miste fatningen, samtidigt med at medarbejdere klandrede ham for at have sendt FN ind i det irakiske morads. Olie-for-mad skandalen om svindel med midlerne i forbindelse med det program, som skulle administrere Saddam Husseins salg af olie til indkøb af humanitære fornødenheder og betaling af krigsskadeerstatning til Kuwait.

Der blev ifølge undersøgelsen svindlet for milliarder - bare ikke i FN. I skrivende stund er der faktisk kun mistanke om bedrageri for relativt små beløb inden for FN's mure. De store beløb hentede regimet på smugleri af olie - noget Sikkerhedsrådet skulle forhindre. $\mathrm{Og}$ så blev 
der svindlet med kontrakter og priser på den officielle handel med olie og importerede varer, penge der enten gik i det irakiske regimes kasse eller blev brugt til bestikkelse. FN var først og fremmest skyldig i ikke at have styr på kontrollen, i sjusk, ligegyldighed og igen - inkompetence.

Kofi Annan, ja han var skyldig i at have en søn, der helt klart har slået seriøst plat på sin fars gode navn og stilling. Men mest af alt var han nok skyldig i på dette tidspunkt klart til BBC at have sagt, at krigen mod Irak var ulovlig. At han så i øvrigt også på et pressemøde i FN offentligt revsede en journalist og kaldte ham en skændsel for sin profession - ja det hjalp ikke ligefrem på generalsekretærens mediedækning. Noget sådant straffer sig. Og især konservative amerikanske medier har gentagne gange krævet generalsekretærens hoved på et fad. Det republikanske parti har haft efterforskere i Ghana og Nigeria, hvor hans første kone stammer fra, for at grave snavs op om ham og familien. Men øjensynligt uden held.

Udadtil taklede FN krisen og mediernes angreb lige så kejtet og ubehjælpsomt, som de øvrige skandaler i de år - FN-soldaters overgreb på kvinder i Congo, Flygtningehøjkommissærens gramsen på kvinder på kontoret, og chef-revisorens uholdbare personalepolitik. Generalsekretæren måtte hente hjælp på den anden side af gaden - hos udviklings- programmet UNDP, hvor hans tidligere kollega Mark Malloch Brown sad som chef. Mark Malloch Brown er en alt andet end soft-spoken britisk-amerikaner og væsentlig hurtigere i replikken end den dominerende, men ikke just imponerende gruppe blandt de faste FN-journalister. Og så kan Mark Malloch Brown det, som tilsyneladende er Kofi Annans svageste punkt. Han kan rydde op - også blandt vennerne.

For selv om olie-for-mad undersøgelsen afslørede overraskende lidt svindel i FN, så pegede den på en del afdelinger, der ikke fungerede som de skulle. Og selv om Annan i hele sin embedsperiode har været god til at ansætte dygtige og stærke ledere og rådgivere, ja så har han også omgivet sig med mange gamle kollegaer. Ikke mindst fra en vis periode i FN's Flygtningehøjkommissariat og fra den fredsbevarende afdeling. Adskillige har været med begge steder. Det er en imponerende samling, mange af dem blandt verdens dygtigste, som Sergio de Mello der døde i Bagdad.

Men selv topdiplomater kan have en begrænset holdbarhed, og Kofi Annan har tilsyneladende altid haft svært ved at se, hvornår udløbsdatoen er overskredet eller måske bare haft svært ved at drage konsekvensen. Han er sine venners ven og ser gerne det bedste i mennesker.

Mark Malloch Brown, der selv er en af flokken fra UNHCR, besidder den nødvendige brutalitet til at gøre 
kort proces. Han fik lynhurtigt renset ud - blandt gamle venner og blandt andre, der var under mistanke for at have opført sig skidt på forskellig vis. Han og generalsekretæren fik sammen med sidste års formand for generalforsamlingen, svenske Jan Eliasson, reddet Verdenstopmødet fra det totale sammenbrud og dermed videreført en del af Annans reformer.

\section{Kofis farvel}

Generalsekretæren selv er mærket af ti års uafbrudt pres fra alverdens kriser og krige og af de personlige angreb på ham og familien. Han er ikke længere en superstar, selv om der igen bliver lyttet med respekt, og de mest angrebslystne journalister og politikere synes at have glemt, at de i en periode havde sat en pris på hans hoved. Angreb, der var uden sammenhæng med næsten en million døde i Rwanda, men derimod handlede om, at han påpegede det, som alle vidste, nemlig at Sikkerhedsrådet ikke havde givet mandat til invasionen af Irak. Og så ikke mindst at sønnen Kojo havde arbejdet for et firma i Vestafrika, som også havde en kontrakt med $\mathrm{FN}$ i Irak, og at Kojo snød for nogle tusind dollar i importafgift af en bil til Ghana ved at lade som om det var hans fars Mercedes.

Det FN, Kofi Annan snart overlader til Ban Ki-Moon, er en forvand- let organisation. Langt fra god nok, det tager mere end ti år med en bestyrelse på 192 medlemmer, som er indbyrdes dybt uenige. Men alligevel gennemgribende forandret til det bedre. Påstande om at FN er totalt irrelevant og ligegyldig, lyder der ikke mange af. USA er med om bord, og alle verdens største problemer, ja de bliver drøftet i FN.

Kofi Annan har fået sat udvikling og menneskerettigheder højt på den dagsorden, der tidligere var domineret af rene sikkerhedsspørgsmål. Han kan kritisere Israel for overdreven brug af magt og slippe godt fra det. Hvert år i september valfarter stats- og regeringsledere til New York for at tale med hinanden og helst også med generalsekretæren i FN.

Kofi Annan har været meget mere end en sekretær, også mere end nogle af de store lande havde ønsket sig. Det burde de have vidst på forhånd. For Boutros Ghali sendte sin alt for populære undergeneralsekretær og formodede rival til Bosnien for blandt andet at stå for overdragelse af hele FN-aktionen til NATO. En stort set umulig opgave at løse til alles tilfredshed. Men Kofi Annan vendte hjem uden en skramme - og formentlig uden at have hævet stemmen.

Kirsten Larsen er FN-medarbejder på Orientering, DR, $P 1$ 